\title{
Major Issues in the Successful Implementation of Information Systems in Developing Countries
}

\author{
Ranjan Vaidya, Michael D. Myers, and Lesley Gardner \\ Department of Information Systems \& Operations Management, \\ University of Auckland Business School, \\ OGGB, 12 Grafton Road, Auckland, New Zealand 1010 \\ $\{r$.vaidya, m.myers, 1 .gardner $\}$ auckland.ac.nz
}

\begin{abstract}
Information systems projects in developing countries continue to fail. Our research aims to understand some of the major issues that negatively impact the success of public sector information systems projects in developing countries. For this, we conducted a qualitative study of a state agricultural marketing board in India. The board initiated an information systems project in 2003. The objective of the project was to connect the various agricultural markets spread across the state by deploying hi-tech information and communication technologies. Unfortunately, the project was abandoned because of the growing conflicts between the government and private vendors implementing the project. The major stakeholders in the project included the government, private vendors, farmers and traders. The data for this critical case study were collected over a period of eight months from 2009 to 2012 using semi structured interviews, field visits and observations. The findings suggest that the lack of trust and resignation (to certain unfair practices being virtually impossible to change) are the core issues that impede success of information systems implementation in developing countries.
\end{abstract}

Keywords: information systems failure, developing countries, critical case study, agricultural marketing.

\section{$1 \quad$ Introduction}

The UN millennium development goals have changed the emphasis of development from economic growth to poverty reduction (Christiaensen, Demery, \& Kuhl, 2010). As almost three fourths of the world's poor live in rural areas and depend on agriculture for their livelihood (Giovannucci et al., 2012), many international developmental institutions are focusing their efforts on improving agriculture in these areas. Poverty reduction can be achieved in a variety of ways e.g. improving agricultural productivity by increasing crop yields, or by improving the supply chain and marketing of agricultural produce.

In this article we focus on how Information and Communication Technology (ICT) can play a decisive role in agricultural marketing. Information about weather forecasts, market prices, and the demand-supply status can be readily accessed and distributed through ICT. In the last two decades many government organisations, non-government 
organisations, and corporate and funding agencies across the developing countries have initiated ICT projects that exclusively deal with agricultural marketing (Banker, Mitra, \& Sambamurthy, 2011; Kamala, 2008).

However, empirical evidence indicates that there are various kinds of problems in the conceptualisation, design and implementation of these projects. In most cases, these projects are conceptualised as price information systems that do not address the marketing asymmetries in the supply chain (Islam \& Grönlund, 2010). They suffer due to various contextual problems such as lack of education and the illiteracy of the farmers (Lokanathan \& De Silva, 2010), lack of supporting policies (Rao, 2007) and intermittent political interference (FAO, 1997). Economically, these projects often do not have proper funding support (Tollens, 2006). The government organisations implementing these tend to be ridden with rigid bureaucracies, corruption and inefficient project management (Islam \& Grönlund, 2010). The situation is further acerbated because agricultural technology adoption is difficult in these developing countries, both because of geographical and cultural reasons (Aker, 2011; Batt, 2001a).

Given these various kinds of problems and issues related to agricultural marketing information systems (AMIS) implementation, this research project seeks to understand the major issues in the successful implementation of AMIS in developing countries. Consequently the research question that it addresses is: What are the major issues in the successful implementation of agricultural marketing information systems in developing countries?

To try to answer this question, the research undertakes a critical case study of the implementation and adoption of an agricultural marketing information system in India. The AMIS was designed to improve the lives of the poor farmers by streamlining the entire auction process, giving them access to price information, and generally improving transparency. The AMIS was implemented in over two hundred market yards (popularly called as Mandi) in one state of India beginning in 2003. Unfortunately however, by 2011-2012 the project was abandoned. This case study provides a good opportunity to understand the major issues in the implementation of AMIS in developing countries.

The paper is structured as follows. In the next section we present a literature review on agricultural marketing information systems. This is followed by the description of our research method. Section four presents the case study of the agricultural marketing board. In section five we present our analysis of the case. Finally, we present our conclusions.

\section{$2 \quad$ Literature Review}

A literature review of seventy six research articles covering the period of thirty five years from 1967 (Abbott, 1967) to 2011 (Ghadiyali, Lad, \& Patel, 2011) indicated three major themes namely; conceptual challenges to AMIS implementation, empirical challenges to AMIS implementation and trust issues in AMIS implementation. Ontologically, the conceptual and empirical challenges together represent the design-reality gap (Heeks, 2002). Trust issues, on the other hand, represent the human issues of implementation. Together these three conceptual elements provide a good picture of the implementation challenges. Each of these is briefly discussed here. 


\subsection{Conceptualization Challenges to AMIS}

Information systems researchers have identified four types of agriculture related information systems. These are knowledge management systems, inspection and certification systems, market information systems and procurement and traceability systems (Parikh, Patel, \& Schwartzman, 2007). A "marketing information system" fails to fall in any of these categories because of the conceptual differences between the terms market and marketing in agriculture. Park (1989) conceptualises agricultural activities as complex business activities rather than a simple means of subsistence. The author sees agricultural marketing as a coordinated activity of farm supplies, harvesting and production, logistics and commodity processing. The author mentions that while price information systems are well conceived, the 'marketing' component has not received adequate attention from developers. Shepherd and Schalke (1995) suggest that marketing is a broader concept that includes "details on potential market channels, payment requirements, packaging, quality and a whole range of other information, including market information." According to Van Crowder (1997), market information alone limits the farmers to react to changes in prices. Marketing information, on the other hand, provides them an opportunity to manoeuvre according to the market dynamics. By and large AMIS have been wrongly conceptualised as price information systems and hence the majority of AMIS projects in developing countries merely capture the price or quantity of agricultural commodities in various retail or wholesale markets (Tollens, 2006).

\subsection{Empirical Challenges in AMIS Implementation}

Researchers have identified various implementation challenges of AMIS. Often organisations implementing AMIS deploy their own staff for collection of data. This results in overhead expenses that cannot be sustained over a long period. Second, there are issues related to public sector organisational culture in developing countries. Researchers have suggested that rigid bureaucracy, corruption and the attitude of government officers in developing countries pose a challenge to information systems implementation generally, and AMIS implementation in particular (Krishna \& Walsham, 2010; Walsham, 2010). AMIS are sometimes deployed to serve the information needs of the government officers rather than the farmers who are meant to be the intended beneficiaries in AMIS (Tollens, 2006). Third, researchers have identified issues with data collection and their accuracy (Islam \& Grönlund, 2010). Fourth, there are contextual challenges to AMIS implementation. AMIS implementation might not be accompanied with changes in the statutory laws as is demonstrated in the echoupal case (Rao, 2007). There are also frequent interventions from the powerful stakeholder groups such as traders and politicians (Shepherd, 1997).

\subsection{Trust Issues in Agricultural Marketing}

Some researchers have highlighted the importance of trust in agricultural marketing. Researchers have suggested that trust is paramount in agricultural marketing as it reduces uncertainty across the agricultural supply chain and trustful relationships are essential for agricultural development (Ballantyne, 2009). Some factors or conditions have a negative impact on trust formation in agriculture marketing in developing countries, for example, use of coercive power by stakeholders, opportunistic behaviour and trader collusion. 
On the other hand, relationship investments, satisfaction with past services, information sharing attitudes and humbleness have a positive impact on trust formation (Banerji \& Meenakshi, 2004; Batt, 2001a; Best, Ferris, \& Schiavone, 2005). Some researchers have suggested that trust formation in agricultural marketing is a long term process (Batt, 2001a, 2001b; Molony, 2008).

Certain behavioural patterns of the stakeholders in agricultural marketing can have an impact on stakeholder trust (Drafor \& Atta-Agyepong, 2005; Jensen, 2010; Mittal, Gandhi, \& Tripathi, 2010). Based on our analysis of seventy six research articles, we were able to identify those agricultural marketing related practices of farmers and traders that have an impact on trust levels between the stakeholders. These are presented in the Table 1.

Table 1. Stakeholders' patterns of behaviour cited by researchers

\begin{tabular}{|c|c|}
\hline Practices of stakeholders & Citation Source \\
\hline Farmers do not abide by their auction contracts. & (Best et al., 2005) \\
\hline $\begin{array}{l}\text { Farmers do not pack their agricultural commodities } \\
\text { properly. }\end{array}$ & \multirow[t]{3}{*}{ (Batt, 2004) } \\
\hline $\begin{array}{l}\text { Farmers do not show a true representative sample } \\
\text { of their commodity to the traders. }\end{array}$ & \\
\hline $\begin{array}{l}\text { Traders exaggerate their purchase prices and under- } \\
\text { quote their selling prices. }\end{array}$ & \\
\hline $\begin{array}{l}\text { Traders make less payment to farmers than the } \\
\text { agreed prices. }\end{array}$ & (Pokhrel \& Thapa, 2007) \\
\hline $\begin{array}{l}\text { Traders do not divulge their purchase information } \\
\text { for fear of being taxed. }\end{array}$ & (Tollens, 2006) \\
\hline Traders do not weigh the commodity correctly. & $\begin{array}{l}\text { (Chengappa, 2003; Kydd \& Dorward, } \\
\text { 2004) }\end{array}$ \\
\hline Traders form cartels to control commodity prices. & (Meenakshi \& Banerji, 2005) \\
\hline Traders control the harvesting of commodities. & (Pokhrel \& Thapa, 2007) \\
\hline $\begin{array}{l}\text { Traders are inclined to offer the lowest possible } \\
\text { prices to farmers. }\end{array}$ & (Goyal, 2010 ; Muto \& Yamano, 2009) \\
\hline $\begin{array}{l}\text { Traders provide seed loans to the farmers on the } \\
\text { condition that the produce will be sold to the } \\
\text { traders at pre fixed prices. }\end{array}$ & (Batt \& Rexha, 1999) \\
\hline Traders provide credits to the farmers. & $\begin{array}{l}\text { (Anupindi \& Sivakumar, 2007; } \\
\text { Blattman, Jensen, \& Roman, 2003; } \\
\text { Molony, 2008; Shepherd, 1997) }\end{array}$ \\
\hline
\end{tabular}

Amongst the three themes discussed above, we focus on trust issues in AMIS implementation from now on. This is for two reasons. First, researchers have suggested that trust formation is critical for the success of agriculture marketing (Almond \& Hainsworth, 2005) and yet trust issues are usually not given adequate importance in AMIS design and implementation(Islam \& Grönlund, 2010). Second, trust (or rather, the lack of trust) was the major issue leading to the failure of the AMIS in our particular case. 


\section{$3 \quad$ Research Method}

We used qualitative case study research, since qualitative research helps the researchers to understand the behaviour of people in the light of their context and values (Myers, 2009). Specifically, we used critical case study research, since critical research in IS "is concerned with social issues such as freedom, power, social control, and values with respect to the development, use, and impact of information technology" (Myers \& Klein, 2011 p.17). The data for the study was collected by one of the authors for a nine month period between 2009 and 2012. The data was collected from 23 semi structured interviews with the stakeholder groups namely farmers, traders, government officers and private partners. The interviews with the government officers and private partners were undertaken at different levels of hierarchy. The interviews with the farmers and traders were undertaken at market yards as well as their villages. These interviews and field visits were carried out at four different yards in the state. At the micro level, the constant comparison method (CCM) proposed by Boeije (2002) was followed to identify the main themes. Thematic analysis was then undertaken as per the guidelines proposed by Braun $\&$ Clarke (2006) leading to the identification of our main findings.

\section{Case Description}

The case study is of a government owned agricultural marketing board in India. The board controls over 200 hundred market yards of the state which are commonly called as Mandi. The farmers bring their produce to these yards where it is auctioned.

Studies indicate that there are large price discrepancies across these market yards and often the farmers are not able to realize the best available prices (Goyal, 2010). Past studies also indicate that farmers face various kinds of problems in the yards such as cheating in commodity weighing, bearing the cost of commodity bags, delays in the payments, etc. These problems have an impact on the socio-psychological wellbeing of the farmers (Anupindi \& Sivakumar, 2007). It is against this background that the board initiated the project to computerize its operations in 2003. The project intended to make the yard operations transparent and help the decision making of the stakeholders, particularly the farmers (Vaidya, Myers, \& Gardner, 2011).

In this project, sixty four yards were selected from the over two hundred yards of the state. The data on auctions and weighing was to be collected through hand held electronic machines. A software application was developed to upload the data to a central server. The collated data on commodity prices and volumes was redistributed to the market yards. In the yards, this data was displayed on computers as well as television sets. This helped the farmers and traders to know the rates prevalent in other neighbouring yards. Also, the website of the board displayed the latest commodity data. The private vendor installed the hardware and also deployed manpower to conduct these tasks on built-ownoperate basis. The vendor charged a fee for their services, which was based on the yard type and ranged between thirteen to seventeen per cent (MAPIT, 2006; Vaidya, 2009).

A 2008 evaluation by the Department of Information Technology, Ministry of Information and Communication Technology, Government of India indicated that the project was a success (DIT, 2008 p.92). However, our visits to the yard in 2010 revealed that conflicts had developed between the private partners and the government on various issues. The government blamed the private partners for not being 
sincere, whereas the government officers complained that the private partners were not sincere. The private partners, on the other hand, blamed the government for lacking the appropriate organisational culture for computerisation. In 2011 the equipment of the private partners was seized by the respective yards. Following this the private partners appealed in the state high court where they lost the case. The reasons for the failure of the project are presented in the next section.

\section{Case Analysis}

Our analysis of the stakeholder interviews revealed that lack of trust was the most important issue in the unsuccessful implementation of the agricultural marketing information systems project. Each stakeholder group regarded the other stakeholder group as dishonest, lacking sincerity and also hegemonic. Nearly all the stakeholders blamed the farmers for not showing the true sample of commodities to the traders. For example, one government officer described this as follows:

"The farmers have different qualities of the commodity. What is shown as the sample is different from the actual commodity. For example on the top of the bag, they keep good quality while in the bottom, they keep the poor quality. The trader cannot inspect the full commodity as the bags and trolleys are too large to be fully opened...so if you go to the yard premises, you will observe that these conflicts are occurring continuously".

All the stakeholders blamed the traders for doing unregistered trade transactions. According to the other stakeholders, traders under reported their commodities in order to save their service charge payments to the yards. One of the private partner employees described this as follows:

"The two per cent service charge that the traders are required to pay brings a lot of difference to them as their transaction gets documented. If documented, they have to pay other taxes such as value added tax or sales tax. Sometimes such taxes may reach as high as twenty per cent of the purchased commodity. Obviously the traders try to avoid it".

The private vendors blamed the government officers for lacking the organizational culture that was necessary for the successful implementation of information systems projects. For example one private partner employee mentioned as follows:

"If any senior officer from the head office comes for a visit to the yard, then all his expenses are borne by the junior government officers. However, I have never seen a junior claiming these expenses from the yard. I fail to understand this, why the junior does not claim these expenses. Is it not his right, is he not entitled to claim these expenses? What is the reason? Why he does not claim these expenses? Sometimes the juniors also ask the private partner to pay for these expenses. Why should the private partner pay for these expenses?"

The government officers blamed the private partners for manipulating their reports in order to prove that computerization was yielding benefits to the yards. This was explained by one government officer as follows: 
"I will give you one more example of the...tricks that private partners play to prove the effectiveness of the IS. The traders submit their records of the transaction usually after ten days. For instance, for the trade done between the $1^{\text {st }}$ and $10^{\text {th }}$ of a month, the trader submits the record on $11^{\text {th }}$. Similarly for the next 10 days, the records are submitted after $20^{\text {th }}$. Obviously, if you check the computerized records on the fifteenth, it will show that some traders have not paid their service charges. So the private partner reports a recovery from the trader, when in effect the truth is that the trader has not yet submitted the records. So the private partners do such false reporting to show that the IS has been successful in recovering the service charge payments. I can say this thing on behalf of the entire board that just to prove that they have made a positive impact on the yard revenue they present wrong information and do all kinds of manipulations".

The government officers also felt that the private partners often emulated the bureaucratic style of functioning of the government. A government officer revealed this as follows:

"If we ask for any new information or any new module, they say that the required information or module can be generated only after the approval or sanction from the Mandi board".

The same officer presented another example that revealed the working of the private partner:

"I will give an example of the things that they (private partner) do. There is a module in their software for the salary records of the Mandi employees. We were instructed by the authorities in the board that we should help them in the computerisation of the salary records. So we were asked by the establishment section to help this process. The private partners wrote us a letter asking that we should provide them the required information related to employees and their salary records. This meant that we should provide them the data in a format. Obviously this implied that we first do the data entry ourselves and then provide them the data. After some time when we asked them as to why they have not started with the data entry of the salary records? Their site in-charge replied that they had already written a letter to us asking for the required information. Now it is their responsibility to enter the data for the 300 staff employed here. If we are asked to provide the data to them, obviously we will need to do the data entry ourselves. So then what's the work of the private partner? We do not have staff for our own works, and they expect that we will have the staff to enter the data of 300 employees. So we told them clearly that our responsibility is to provide you with the records and not the data and so we will provide you the records and you are supposed to feed these records in your system".

An integrated model of trust formation, based on each stakeholder group's perception about the other stakeholder group, is presented in figure 1. The model presents four key constructs that contribute to trust formation. These include stakeholder attitude, stakeholder sincerity, stakeholder honesty and stakeholder efficiency. Within stakeholder attitude, it suggests that hegemonic attitude has negative implications on trust formation. 


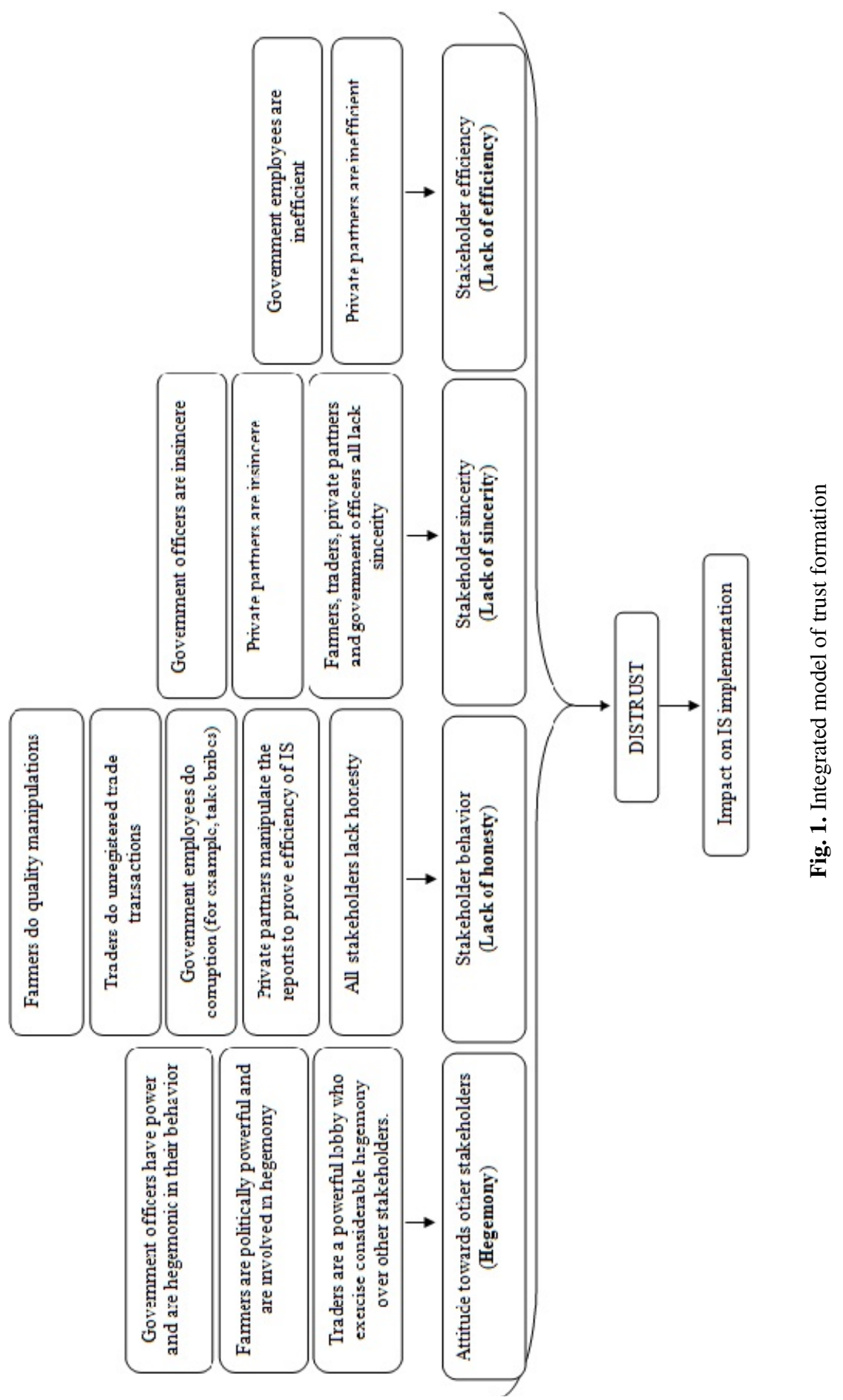


The discussion above demonstrates that stakeholder trust was a key issue in the unsuccessful implementation of this agricultural marketing information system. Our evidence suggests that indeed yard stakeholders did not trust each other and that they blamed the other stakeholder group for various problems present in the yard. But at the same time our empirical evidence indicated that yard stakeholders were aware about their own behaviour that had a negative impact on functioning of the yards. For instance, farmers were aware of their involvement in the acts of quality manipulations. The traders accepted that it was common for them to under-report their trade transactions; and the government officer readily agreed to the fact that they did "corruption". Table 2 presents some excerpts, in which the stakeholder groups indicated that they were well aware of their own behaviour.

Table 2. Stakeholder excerpts on behavioural self-awareness

\begin{tabular}{|l|l|}
\hline Trader & $\begin{array}{l}\text { Some companies do not register their purchase of the soya. Then } \\
\text { they sell the processed soya products such as de-oiled cakes, oil, etc. }\end{array}$ \\
\hline Government Officer & $\begin{array}{l}\text { See I am not a puritan ....even I do a little (comuption)... but only as } \\
\text { per my requirement... }\end{array}$ \\
\hline Farmers & $\begin{array}{l}\text {...farmers did not provide the promised quality to the } \\
\text { companies....instead they mixed the lower varieties with the higher } \\
\text { ones... }\end{array}$ \\
\hline
\end{tabular}

This indicates that each stakeholder group was involved in certain activities that had a negative impact on trust, but at the same time, the stakeholders were also aware of their behaviour. This suggests that everyone knew what the others were doing. It seems as if each stakeholder accepted the untrustworthy behaviour of the other stakeholder, including themselves, in spite of being aware that such behaviour had a negative impact on the overall functioning of the yard. This can be understood from the following excerpt by a government officer:

"It is the weighing process that is the most problematic because those who weigh the commodity, they harass the farmers a lot. They will not weigh the commodity timely; they will not weigh the commodity properly. The weighing labourers are very rude and rash, some of them are not worth talking to. But the farmer keeps his patience, he tolerates everything... he has to tolerate everything...he cannot help it...if he fights or opposes, his payment is delayed...so he tolerates everything..."

Observe here that the government officer mentions that the labourers who weigh the commodity are hegemonic, dishonest and insincere in fulfilling their responsibilities. However, the officer also mentions that the farmers tolerate such behaviour of the labourers. This suggests that stakeholders have a high sense of resignation as they have no other alternatives to the yard.

Another excerpt from a farmer will further establish that resignation along with mistrust presents a major challenge for the functioning of the yards. This excerpt relates to a discussion with a farmer who had just completed the weighing of the commodity. There was some conflict between the labourers and farmers while the weighing was still in progress. After the conflict de-escalated, one of the authors 
approached the farmers and asked them about the conflict. The farmer described the conflict as follows:

"Actually it is the duty of the labourer to weigh the commodity. He is required to lift the commodity from the vehicle and put it on the weight balance. He is also required to remove it from the weigh balance but they do not do the entire work. So the labour did not come to do this work yet we had to pay to the labourer. So that is what happens here...so they got their labour charges even when they had not done the labour...the rule of the Mandi is that the labourer will weigh the commodity and then will take the charges from us...but here as you may have seen we paid the labourer charges even when they did not do any labour...see if there is a big lot...say in a truck ...then the labours take interest in unloading it...else they do not take interest... and suppose we tell them that we need no labour...then they will weigh our commodity late in the evening.... and hence we will be relieved later...so we gave them 50 rupees and also did the labour on our own...so that we may be relieved quickly from the yard...see one of us has come from 20 kilometres and another has come from 30 kilometres..."

The foregoing statement clearly suggests that the farmers agreed to pay the labour charges in spite of the fact that the labourers did not do any labour. The farmer also describes the repercussions of not paying to the labourer - "so that we may be relieved quickly from the yard". The farmer was fearful that if he will not pay to the labourers, it will have certain consequences i.e., he will not be relieved from the yards timely or that his payments will be delayed. This fear of further delay in the yards, to the already exhausted farmer, forces him to succumb to the whims of the labourers. Of course, farmers mistrust the labourers, but the economic circumstances are such that, in spite of this mistrust, the farmers resign themselves to participating in transactions with them.

Let us look at another example. The government officers, both senior level and junior level, are well aware that the farmers are involved in quality manipulations, yet they are not willing to install quality checking mechanisms in the yards. For example, one government officer mentioned that quality problems are a prime source of conflicts in the yards and that there were no facilities in the yards to grade the commodity quality. For example, one government officer mentioned this as follows:

"The farmer does not have grading equipment for these different commodities. So if we can install these different grading machines in the yard such conflicts will be reduced. So computerisation should look into these aspects also".

In spite of awareness about this issue - an issue that is prevalent for a long time - the government officers ignored the problem and made no effort to resolve it. On another occasion, the same government officer mentioned that he was not promoted for years and the first promotion that he received was after twenty seven years of service. His concluding remarks are as follows:

"why should I be any more interested so, slowly, I have now become disinterested in the affairs of the yard...let it go...who cares..." 
This attitude clearly suggests that the yard officer had become disinterested in resolving the problems in the yards. This again suggests that stakeholders are well aware of the precise nature of yard issues, but they become reluctant to resolve them for various reasons. Clearly there are two issues here: reluctance to confront the issues in appropriate forums and mistrust. The former is resignation. Our analysis reveals that mistrust and resignation were the two major issues that had a negative impact on the implementation of this agricultural marketing information system.

\section{Discussion and Conclusions}

Our findings have revealed that mistrust and stakeholder resignation were the major issues that negatively impacted the successful implementation of this agricultural marketing information systems. We believe that our findings may be applicable to similar projects in other developing countries. Researchers studying agricultural ICT implementation in developing countries such as Tanzania and Dar es Salaam have argued that trust relationships between the farmers and traders are important for the successful implementation of ICT projects (Molony, 2008). Trust is an important success factor in situations characterised by uncertainty, risks and incomplete buyer information (Batt, 2001a, 2003; Batt \& Rexha, 1999).

However, overcoming lack of trust is difficult in developing countries, given that they are characterised by poverty, exploitation and corruption. Our findings clearly demonstrate that honesty, efficiency and sincerity were missing amongst all the stakeholders. To counter exploitation and corruption, stakeholders adopt practices of dishonesty and hegemony themselves: it is a cycle that keeps repeating itself.

We have suggested that low levels of trust and helplessness result in the resignation of stakeholders. Past studies have also suggested that mistrust becomes a chosen strategy of stakeholders when there is an expectation of selfish behaviour from other stakeholders (Baba, 1999). Hence we conclude that trust and resignation are the core issues in the successful implementation of information systems in developing countries.

\section{References}

Abbott, J.C.: Agricultural Marketing Boards in the Developing Countries. Journal of Farm Economics 49(3), 705 (1967)

Aker, J.C.: Dial "A" for agriculture: a review of information and communication technologies for agricultural extension in developing countries. Agricultural Economics 42(6), 631-647 (2011)

Almond, F., Hainsworth, S.: Beyond Agriculture-Making Markets Work for the Poor. In: Proceedings of an International Seminar, Westminister, London, UK. Crop Post-Harvest Programme (CPHP). Natural Resources International Limited, Aylesford, Kent and Practical Action, Bourton on Dunsmore, Warwickshire, UK, Febrauary 28 -March 1, p. 176 (2005)

Anupindi, R., Sivakumar, S.: Supply Chain Reengineering in Agri-Business. In: Lee, H.L., Lee, C.Y. (eds.) Building Supply Chain Excellence in Emerging Economies, vol. 98, pp. 265-307. Springer US (2007)

Baba, M.L.: Dangerous liaisons: Trust, distrust, and information technology in American work organizations. Human Organization 58(3), 331-346 (1999)

Ballantyne, P.: Accessing, Sharing and Communicating Agricultural Information for Development: emerging trends and issues. Information Development 25(4), 260-271 (2009)

Banerji, A., Meenakshi, J.V.: Millers, Commission Agents and Collusion in Grain Auction Markets: Evidence From Basmati Auctions in North India. Centre for Development Economics, Delhi School of Economics Working Paper Series 129 (2004) 
Banker, R., Mitra, S., Sambamurthy, V.: The effects of digital trading platforms on commodity prices in agricultural supply chains. MIS Quarterly 35(3), 599-A593 (2011)

Batt, P.J.: Building Trust in the Filipino Seed Potato Industry. Journal of International Food and Agribusiness Marketing 13(4), 23-41 (2001a)

Batt, P.J.: Factors Influencing a Potato Farmer's Choice of Seed Supplier: Empirical Evidence from the Philippines. Journal of International Food and Agribusiness Marketing 12(2), 71-91 (2001b)

Batt, P.J.: Building trust between growers and market agents. Supply Chain Management 8(1), 65-78 (2003)

Batt, P.J.: Incorporating measures of satisfaction, trust and power-dependence into an analysis of agribusiness supply chains. In: Johnson, G.I., Hofman, P.J. (eds.) Agriproduct Supply Chain Management in Developing Countries. Proceedings of a Workshop Held in Bali, Indonesia, August 19-22, vol. 119, p. 194. ACIAR (Australian Council for International Agricultural Research) (2003)

Batt, P.J., Rexha, N.: Building Trust in Agribusiness Supply Chains: A Conceptual Model of Buyer-Seller Relationships in the Seed Potato Industry in Asia. Journal of International Food and Agribusiness Marketing 11(1), 1-17 (1999)

Best, R., Ferris, S., Schiavone, A.: Building linkages and enhancing trust between small-scale rural producers, buyers in growing markets and suppliers of critical inputs. Paper Presented at the CPHP Workshop on Beyond Agriculture: Making Markets Work for the Poor, London (2005), http: / /www. cphp. uk. com/uploads / documents /CPHPTheme\%2 0papers .pdf

Blattman, C., Jensen, R., Roman, R.: Assessing the Need and Potential of Community Networking for Development in Rural India. The Information Society 19(5), 349-364 (2003)

Boeije, H.: A Purposeful Approach to the Constant Comparative Method in the Analysis of Qualitative Interviews. Quality \& Quantity 36(4), 391-409 (2002)

Braun, V., Clarke, V.: Using thematic analysis in psychology. Qualitative Research in Psychology 3(2), 77-101 (2006)

Chengappa, P.G.: Institutional Aspects of Agricultural Marketing in India. In: Pal, S., Mruthyunjaya, Joshi, P.K., Saxena, R. (eds.) Institutional Change in Indian Agriculture, National Centre For Agricultural Economics And Policy Research, New Delhi (2003)

Christiaensen, L., Demery, L., Kuhl, J.: The (Evolving) Role of Agriculture in Poverty Reduction. UNU-WIDER Working Paper, 36, 1-37 (2010)

DIT. Draft Report on Impact Assessment of e-Governance Projects. New Delhi: Department of Information Technology, Government of India (2008)

Drafor, I., Atta-Agyepong, K.: Local information systems for community development in Ghana, vol. 9. Rome: Agricultural Support Systems Division, FAO (2005)

FAO. Market information services. Theory and practice, Rome: FAO (1997)

Ghadiyali, T., Lad, K., Patel, B.: Agriculture Intelligence: An Emerging Technology for Farmer Community. Paper Presented at the Second International Conference on Emerging Applications of Information Technology (EAIT), Februaury 19-20 (2011)

Giovannucci, D., Scherr, S., Nierenberg, D., Hebebrand, C., Shapiro, J., Milder, J., Wheeler, K.: Food and Agriculture: the future of sustainability. A strategic input to the Sustainable Development in the 21st Century (SD21) project. New York United Nations Department of Economic and Social Affairs, Division for Sustainable Development (2012)

Goyal, A.: Information, Direct Access to Farmers, and Rural Market Performance in Central India. American Economic Journal: Applied Economics 2(3), 22-45 (2010)

Heeks, R.: Information System in Developing Countries: Failure, Success, and Local Improvisations. The Information Society 18, 101-112 (2002)

Islam, M.S., Grönlund, Å.: Agriculture Market Information Services (AMIS) in the Least Developed Countries (LDCs): Nature, Scopes, and Challenges. In: Wimmer, M.A., Chappelet, J.-L., Janssen, M., Scholl, H.J. (eds.) EGOV 2010. LNCS, vol. 6228, pp. 109-120. Springer, Heidelberg (2010) 
Jensen, R.T.: Information, efficiency, and welfare in agricultural markets. Agricultural Economics 41, 203-216 (2010)

Kamala, G.: ICT use by businesses in rural India: The case of EID Parry's Indiagriline. International Journal of Information Management 28(4), 336-341 (2008)

Krishna, S., Walsham, G.: Implementing public information systems in developing countries: Learning from a success story. Information Technology for Development 11(2), 123-140 (2010)

Kydd, J., Dorward, A.: Implications of market and coordination failures for rural development in least developed countries. Journal of International Development 16(7), 951-970 (2004)

Lokanathan, S., De Silva, H.: Leveraging Mobile 2.0 in India for Agricultural Market Access. SSRN eLibrary (2010)

MAPIT. E-Agricultural Marketing in Madhya Pradesh (2006), http://www.iimahd. ernet.in/egov/ifip/dec2006/article1.htm (retrieved)

Meenakshi, J.V., Banerji, A.: The unsupportable support price: an analysis of collusion and government intervention in paddy auction markets in North India. Journal of Development Economics 76(2), 377-403 (2005)

Mittal, S., Gandhi, S., Tripathi, G.: Socio-Economic Impact of Mobile Phones on Indian Agriculture. Indian Council for Research on International Economic Relations, Working Paper No. 246 (2010)

Molony, T.: Running out of credit: the limitations of mobile telephony in a Tanzanian agricultural marketing system. The Journal of Modern African Studies 46(04), 637-658 (2008)

Muto, M., Yamano, T.: The Impact of Mobile Phone Coverage Expansion on Market Participation: Panel Data Evidence from Uganda. World Development 37(12), 1887-1896 (2009)

Myers, M.D.: Qualitative Research in Business \& Management. Sage Publications, London (2009)

Myers, M.D., Klein, H.K.: A set of principles for conducting critical research in information systems. MIS Q 35(1), 17-36 (2011)

Parikh, T., Patel, N., Schwartzman, Y.: A survey of information systems reaching small producers in global agricultural value chains. Paper Presented at the International Conference on Information and Communication Technologies and Development (2007)

Park, S.: Market information and price reporting systems in food and agricultural sector. Journal of Rural Development 12(1), 19-47 (1989)

Pokhrel, D.M., Thapa, G.B.: Are marketing intermediaries exploiting mountain farmers in Nepal? A study based on market price, marketing margin and income distribution analyses. Agricultural Systems 94(2), 151-164 (2007)

Rao, N.H.: A framework for implementing information and communication technologies in agricultural development in India. Technological Forecasting and Social Change 74(4), 491-518 (2007)

Shepherd, A.S.: Market Information Services: Theory and Practice. FAO, Rome (1997)

Shepherd, A.W., Schalke, A.J.F.: The Indonesian horticultural market information service. FAO, Rome (1995)

Tollens, E.F.: Market Information Systems in sub-Sahara Africa Challenges and Opportunities. Paper Presented at the International Association of Agricultural Economists Conference, Gold Coast, Australia (2006)

Vaidya, R.: Computerization of Agricultural Marketing Board: Lessons from Madhya Pradesh, India. Information Technology in Developing countries 19(1), 8-12 (2009)

Vaidya, R., Myers, M.D., Gardner, L.: The Design - Reality Gap: The Impact of Stakeholder Strategies on IS Implementation in Developing Countries. In: Nüttgens, M., Blinn, N. (eds.) Governance and Sustainability in IS. IFIP AICT, vol. 366, pp. 119-134. Springer, Heidelberg (2011)

Van Crowder, L.: Marketing Information Systems for Small-Scale Farmers. Information Development 13(4), 179-183 (1997)

Walsham, G.: ICTS for the broader development of India: An analysis of the literature. EJISDC 41(4), 1-20 (2010) 